\title{
OPPORTUNITIES FOR CROSS-BORDER COOPERATION BETWEEN BULGARIA AND ROMANIA: THE CASE OF THE INTERREG PROGRAME
}

\author{
T. Turlakova, G. Slavova, T. Georgieva \\ University of Economics - Varna, Bulgaria
}

\begin{abstract}
European Territorial Cooperation Programs, better known as INTERREG, support the European Strategy for Smart, Sustainable and Inclusive Growth for Economic, Social and Territorial Cohesion (Europe 2020). The purpose of this paper is to analyze the economic and social problems together with some opportunities in initiating joint activities between participating border regions of Romania and Bulgaria under the Interreg V-A Romania-Bulgaria Programme 2014-2020. Research implications that we draw from our results suggest potential improvements in cross-border partnership and projects. From the conclusions drawn, the generalizations appropriate for the future development of the crossborder cooperation between Bulgaria and Romania covering the period after 2020 can be summarized.
\end{abstract}

Key words: cross-border cooperation; Northeastern Bulgaria, Romania; economic initiatives; problems; opportunities

Cross-border cooperation in Europe, perceived as a process of organized interaction between border regions, originated in the 1950s. Its genesis is the initiative and the desire of regional and local authorities to integrate with their neighbors to expand their capacity in order to increase their opportunities to solve internal problems. This activity has always been strictly within the law and in harmony with the actions of the central authorities. Cross-border cooperation as a practice first emerged on the Scandinavian Peninsula and on the banks of the Rhine river. A European Framework Convention on Cross-Border Cooperation, which Bulgaria ratified in 1999, was adopted in Madrid in 1980. 33 countries have joined the Convention so far, including neighboring Romania and Turkey. The Charter of European Border and Cross-Border Areas was adopted in the following year. It aims to overcome past negatives between neighboring countries, as well as the stagnation in the economy, the territorial imbalances, and to develop and improve the territorial structure. Cooperation between border regions is seen as a test of full integration into Europe.

The implementation of cross-border cooperation is carried out following a programbased approach. The funding of programs is done by the EU and through national funding from participants' own funds and from their state budgets.

Bulgaria has been gradually involved in the processes of cross-border cooperation since 1999 with the adoption of the Regional Development Act [2]. The first step was to identify areas for targeted support [3].

The notion "cross-border cooperation" has not been legally formulated. Meaningfully it comprises any organized action undertaken by two or more territorial units from two or more state borders, which leads to overcoming their problems and developing mutually advantageous relations in all spheres of the socio-economic, spiritual and political life.

The aim of the European Territorial Cooperation is to provide assistance in border regions primarily for the development of crossborder economic, social and environmental activities through joint sustainable territorial development strategies. European Territorial Cross-Border Cooperation makes a significant contribution to the renewed Lisbon Strategy. [1]

Cross-border cooperation is part of the territorial cooperation funded by the European 
Regional Development Fund (ERDF). Territorial cooperation is designed to support the harmonious and balanced integration of the EU territory by fostering cooperation in areas relevant to the community at cross-border, transnational and interregional level [4].

The objectives of cross-border cooperation can be grouped as follows:

- convergence and development of democratic human values;

- enhancing the socio-economic development of the cooperating regions.

The first EU Border Development and Interregional Cooperation (INTERREG I) programme (1991-1993) covered areas comprising all internal and external land borders at NUTS III administrative level (for Bulgaria this is the level of the 28 districts ) as well as some sea borders. With small modifications, INTERREG II (1994-1999) covered the same areas. The INTERREG III A programme, in its section on cross-border cooperation, is also at NUTS III level.

Programme initiatives are grouped differently into specific projects depending on the stage of development of cross-border relations.

The new cross-border cooperation programmes at the internal European borders Bulgaria and Romania 2014-2020 continue the traditions of the Phare CBC Bulgaria - Romania (19982006) and CBC (2007-2013) cross-border cooperation programs. Since 1998, Bulgaria and Romania have implemented cross-border projects, co-financed by the EU, amounting to EUR 8 million a year for each country, mainly in the fields of transport, the environment and "people-to-people" activities, or so-called small projects. The Operational Program for INTERREG V-A for the period 2014-2020 is based on the existing program framework of PHARE-CBC and INTERREG-IIIA.

The purpose of this paper is to analyze the economic and social problems and opportunities of the border regions of both countries to initiate joint activities and initiatives under the Interreg programme (2014-2020) and beyond.

"INTERREG V-A Romania - Bulgaria" program comprises 7 counties in Romania: Constanta, Dolj, Olt, Teleorman, Giurgiu, Calarasi, Mehedinti and 8 districts in Bulgaria - Vidin, Vratsa, Montana, Pleven, Veliko Tarnovo, Dobrich. [5] The INTERREG programme finances investment projects in the field of improving transport links, ecosystems, risk management, employment, capacity building for public institutions, health, and the development of joint tourism projects. The main objective of the "INTERREG V-A Romania - Bulgaria" programme is to build a constructive partnership between the two countries so as to achieve the desired economic and social outcomes of joint actions under the programme and to ensure a sustainable impact on the development of the border region. [6]

Eligible activities are divided into five Priority Axes (PA): 1 "Well-Linked Region", 2 "Green Region", 3 "Secure Region", 4 "Qualified and Inclusive Region" and 5 "Efficient Region".

The total budget of the Bulgaria Romania Cross-Border Cooperation Program for 20142020 is over EUR 258 million. The funding for the first call for proposals is over EUR 208 million, of which some EUR 181 million $(87 \%)$ are earmarked for investment projects and over EUR 27 million (13\%) for soft measures. [ 8] The total budget for the second call for Priority Axes 4 and 5 is over EUR 30 million. More than EUR 17 million is the funding available for Axis 4 approved projects and over EUR 12 million for Axis 5. The third call for proposals to fund projects to meet the program's objectives within axes 1, 2 and 3 has a total budget of more than 109 million and the general allocation is: over 59 million euro for Axis 1, over 34 million euro for Axis 2, and over 15 million euros for Axis 3.[14] 140 applications with a budget of 270 million euro were approved at the ninth meeting of the Monitoring Committee under INTERREG V-A Romania - Bulgaria out of a total of 228 applications submitted during the first phase of the third call for proposals. At present, 79 financing contracts have been concluded under INTERREG V-A Romania - Bulgaria with a budget of over 101 million euros. [14] This is more than $50 \%$ of the available INTERREG budget. On the Bulgarian side, the projects under the cross-border programme were cochaired by Deputy Minister of Regional Development and Public Works Denitsa Nikolova. [9]

Beneficiaries of INTERREG VA Romania Bulgaria are primarily district councils or district administrations, local councils or municipalities, associations of local public authorities, chambers of commerce or associations of small and medium enterprises, universities, ministries, non-profit research 
institutes, other non-governmental organizations whose scope of activities corresponds to the areas of intervention financed by the Programme. All of them will remain unchanged for the next programming period. [10] A key condition for cross-border projects to meet is that they are implemented by partners on both sides of the border, ie Bulgaria and Romania, and have a visible and sustainable effect on the eligible territory. [6] Along with these more general criteria, there are some specific requirements that are detailed in each of the calls for proposals under the cross-border program. The information provides the Bulgarian and Romanian partners with clarity about the priorities, the specific activities, the indicators and the results they have to achieve with their ideas. [7] To date, 79 funding contracts have been approved under the program, with a budget of over 101 million euros. [14] They are concluded under the three separate calls under the program.

The following figure shows all approved and funded projects by type and number related to the cross-border program between Bulgaria and Romania for the period 2007-2020.

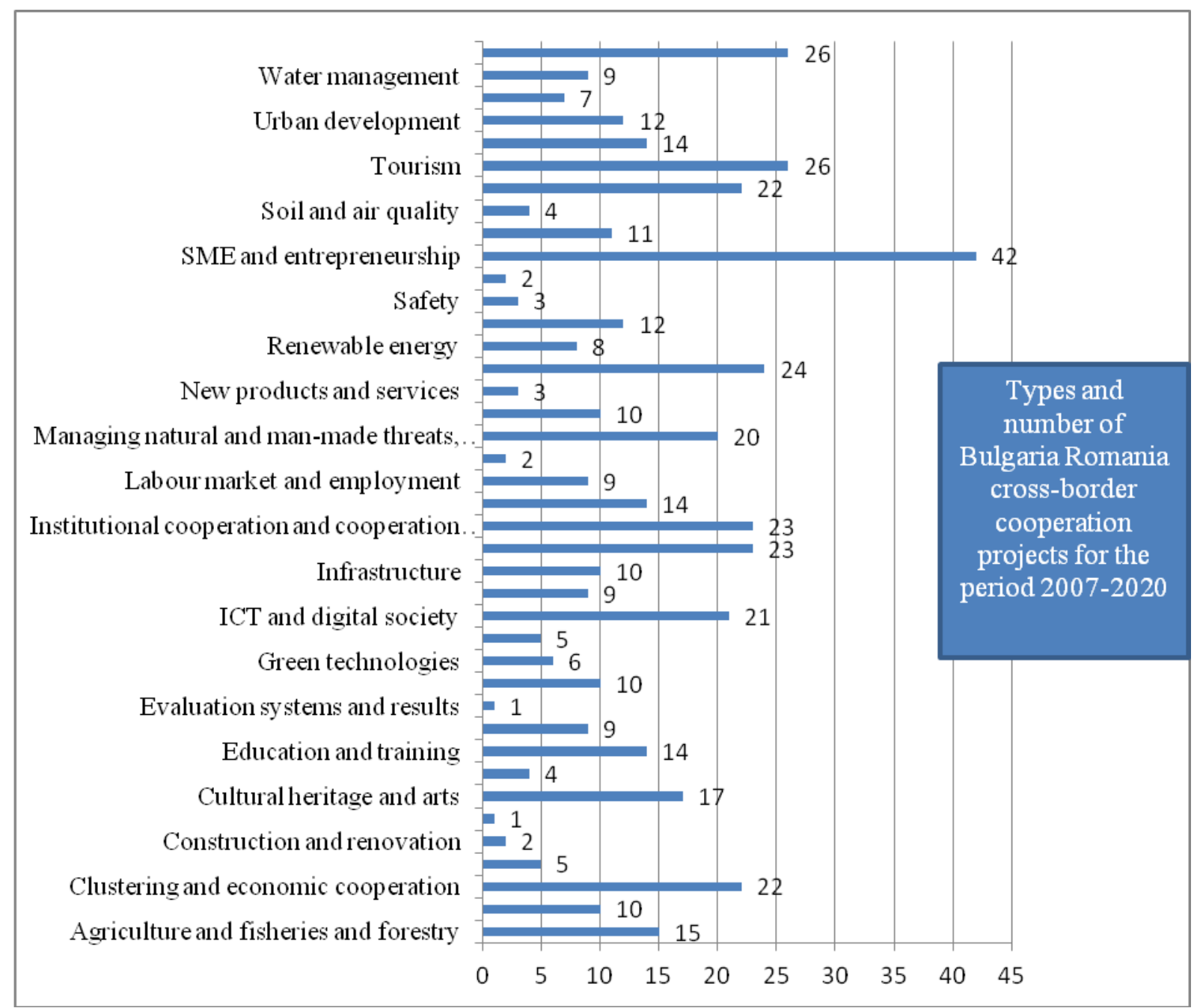

Figure 1. Types and number of Bulgaria Romania cross-border cooperation projects for the period 2007-2020

It is clear from Figure $\mathbf{1}$ that the approved projects aimed at the development of entrepreneurship in small and medium enterprises on the two borders of the Danube River as well as the projects related to the development of border and joint tourism and management of the waterways of the Danube border areas have the largest share. Second come projects related to institutional cooperation and cooperation of ideas, as well as projects related to the creation of innovative products and the introduction of new technology, projects related to healthy lifestyles and maintaining the road infrastructure as well as the whole technical structure in the two border regions in good condition and projects related to the forestry 
sector, fish production and agrarian development.

During the second programming period covering the years 2014-2020 under the crossborder cooperation program 274 projects were submitted following the first call for Priority Axes 1, 2 and 3. [12] Exactly 117 projects are of the "soft measures" type, 36 of which are proposed for funding and 26 grant contracts totaling over $€ 19$ million have been signed. The projects are under implementation.

Figures 2, 3 and 4 show the submitted and approved projects under the three calls for Axes 1, 2 and 3, as follows: 1 "Well-connected region", 2 "Green region", 3 "Secure region" for the 2014-2020 period.

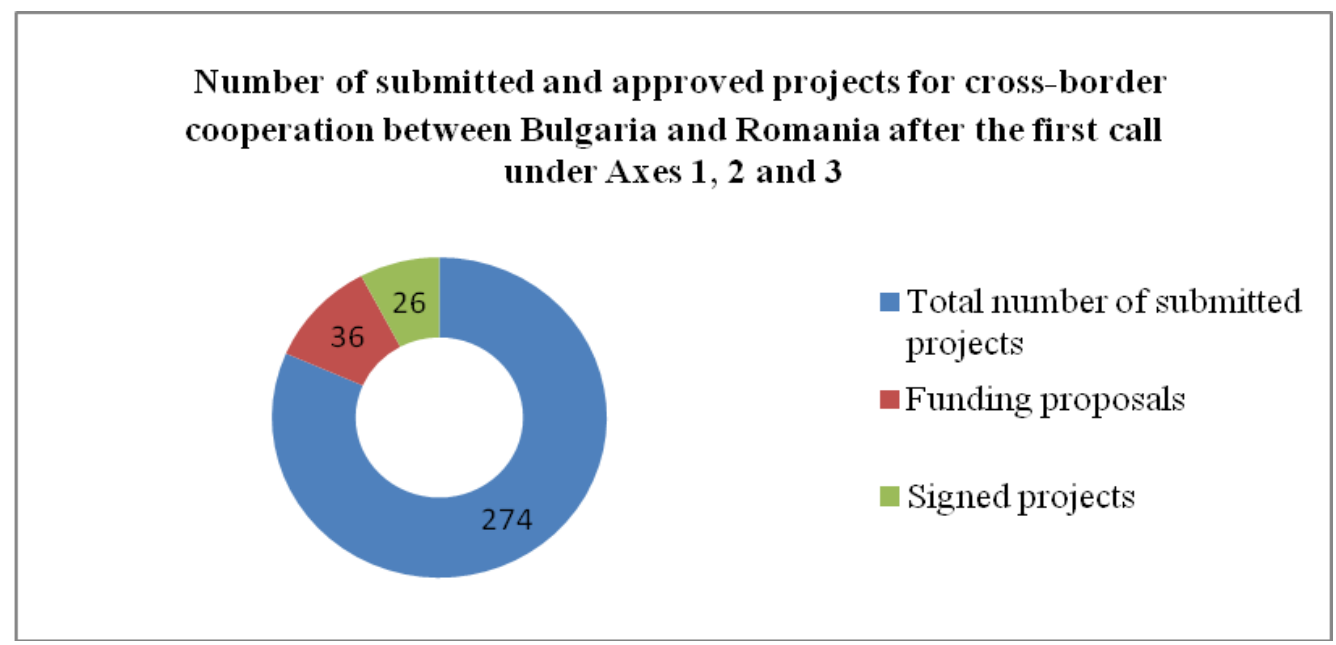

Figure 2. Submitted, approved and signed cross-border cooperation projects between Bulgaria and Romania under the first call for priority axes 1,2 and 3 .

It can be concluded from figure 1 that only $13,13 \%$ of submitted project proposals after the first call under axes 1,2 and 3 have been proposed for funding and only $9,5 \%$ have actually been financed. The project proposals for the second call of the three axes are fewer in number - in total 157 applications have been submitted. (Figure 3)

\section{Number of submitted and approved projects under axes 1,2 and 3 of the Bulgaria Romania cross-border cooperation programme, second call for proposals}

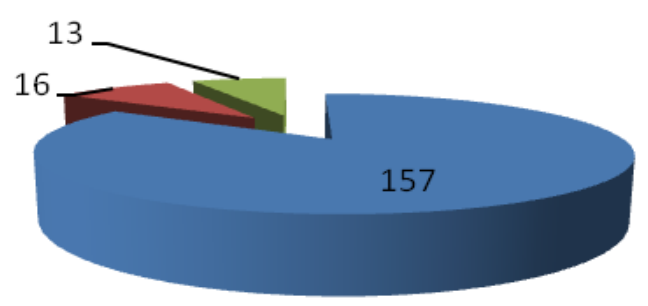

Total number of
submitted projects
Funding proposals

- Signed projects

Figure 3. Submitted, approved and signed projects for Bulgaria Romania cross-border cooperation under priority axes 1,2 and 3 , second call for proposals

This means that of the total number of applications during the second call for the Bulgaria Romania cross-border cooperation programme under the following priority axes: 1 "Well-connected region", 2 "Green Region", 3 "Sacure region" for the period, only $10.19 \%$ have been approved for financing and $8.28 \%$ of all submissions for the three axes have been signed for implementation. Things were much better at the time of the third call under the three axes. It can be seen from Figure 4 that the number of submitted project proposals is bigger, however there is no such big difference between the proposed and implemented projects under the Programme. 


\section{Number of submitted and approved projects under axes 1,2, and 3 of the Bulgaria Romania cross-border cooperation}

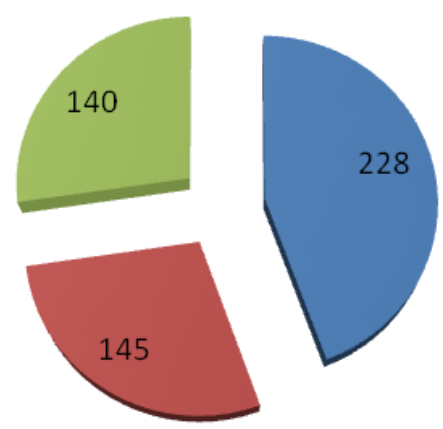

Total number of submitted projects

- Funding proposals

= Signed projects

Figure 4. Submitted, approved and signed projects for Bulgaria Romania cross-border cooperation under priority axes 1,2 and 3 , third call for proposals

Figure 4 shows that the percentage of projects proposed for funding and the projects actually signed for implementation is almost the same, or if we look at the figures in more detail, we will find that $63.6 \%$ of the project proposals were proposed for funding, while the signed projects under implementation represent $61.4 \%$.

The next figure shows the total value of Bulgaria Romania cross-border cooperation projects in million euro under priority axes 1,2 and 3. It is clear from the figure that the largest financial resource was allocated during the third tranche at the time of the third call for proposals for the development of first, second and third priority axes, or mathematically expressed, $77,58 \%$ of all funds allocated in the three tranches were provided during the third call, $16,95 \%$ or approximately $17 \%$ during the second call, and only $5.45 \%$ during the first call.

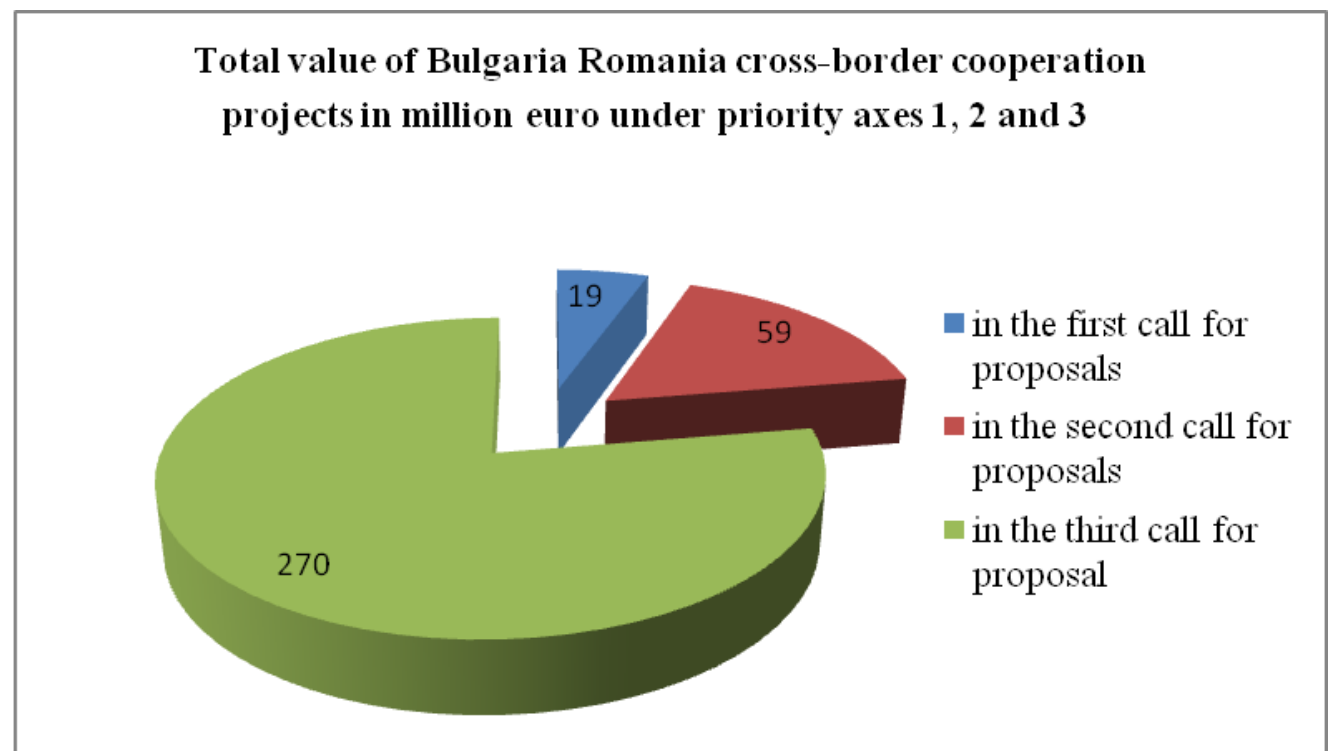

Figure 5. Total value of Bulgaria Romania cross-border cooperation projects in million euro under priority axes 1,2 and 3

Table 1 contains information about the project proposals under priority axes 4 and 5 , of which 56 proposals have been approved for funding amounting to over EUR 35 million. Currently (by June 2019) 48 contracts have been concluded for subsidies amounting in excess of EUR 27,606 mln. 
TURLAKOVA T., et al.

Table 1. Total proposed and approved projects under priority axes 4 and 5 of Romania Bulgaria cross-border cooperation programme

\begin{tabular}{|l|l|l|l|l|}
\hline $\begin{array}{l}\text { Submitted } \\
\text { project } \\
\text { proposals }\end{array}$ & $\begin{array}{l}\text { Projects } \\
\text { approved } \\
\text { for funding }\end{array}$ & $\begin{array}{l}\text { Total value } \\
\text { in mln euro }\end{array}$ & $\begin{array}{l}\text { Signed } \\
\text { contracts for } \\
\text { subsidy }\end{array}$ & $\begin{array}{l}\text { Amount of the provided } \\
\text { subsidy in mln euro }\end{array}$ \\
\hline 211 & 56 & 35 & 48 & 27,606 \\
\hline
\end{tabular}

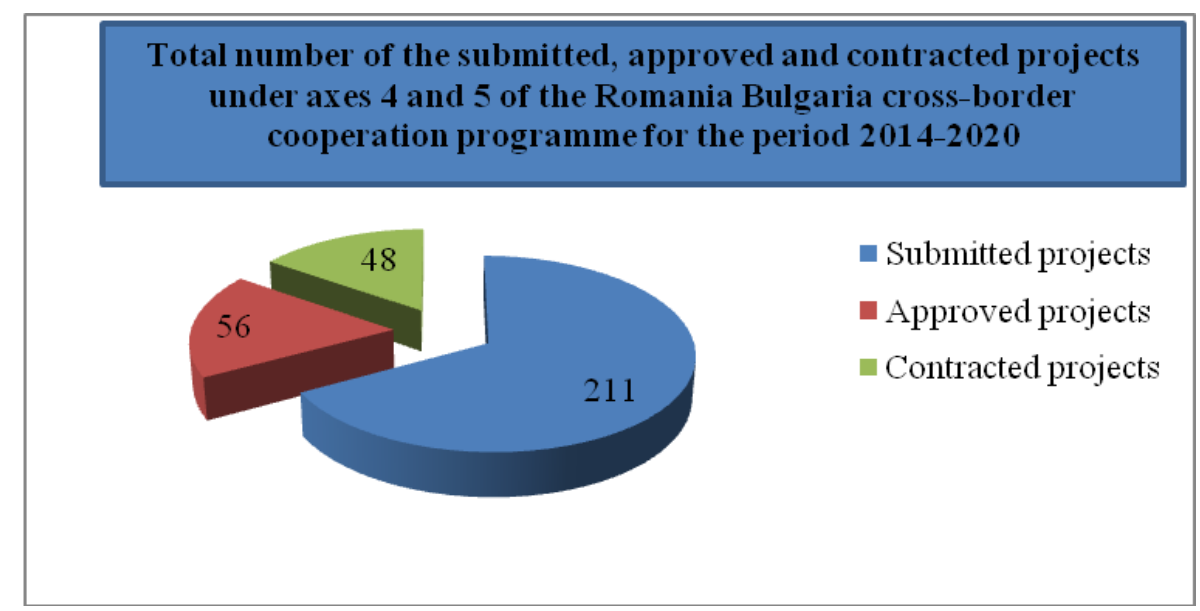

Figure 6. Total number of the submitted, approved and contracted projects under axes 4 and 5 of the Romania Bulgaria cross-border cooperation programme for the period 2014-2020

Figure 6 shows the total number of projects received and approved for funding, which is significantly lower than the number of projects under Axes 1, 2 and 3. This dependence is explained by the fact that Priorities 4 "Qualified and Inclusive Region" and 5
"Efficient Region" are less attractive for beneficiaries applying for the cross-border programme. The following figure 7 shows the percentage of received, approved and funded projects.

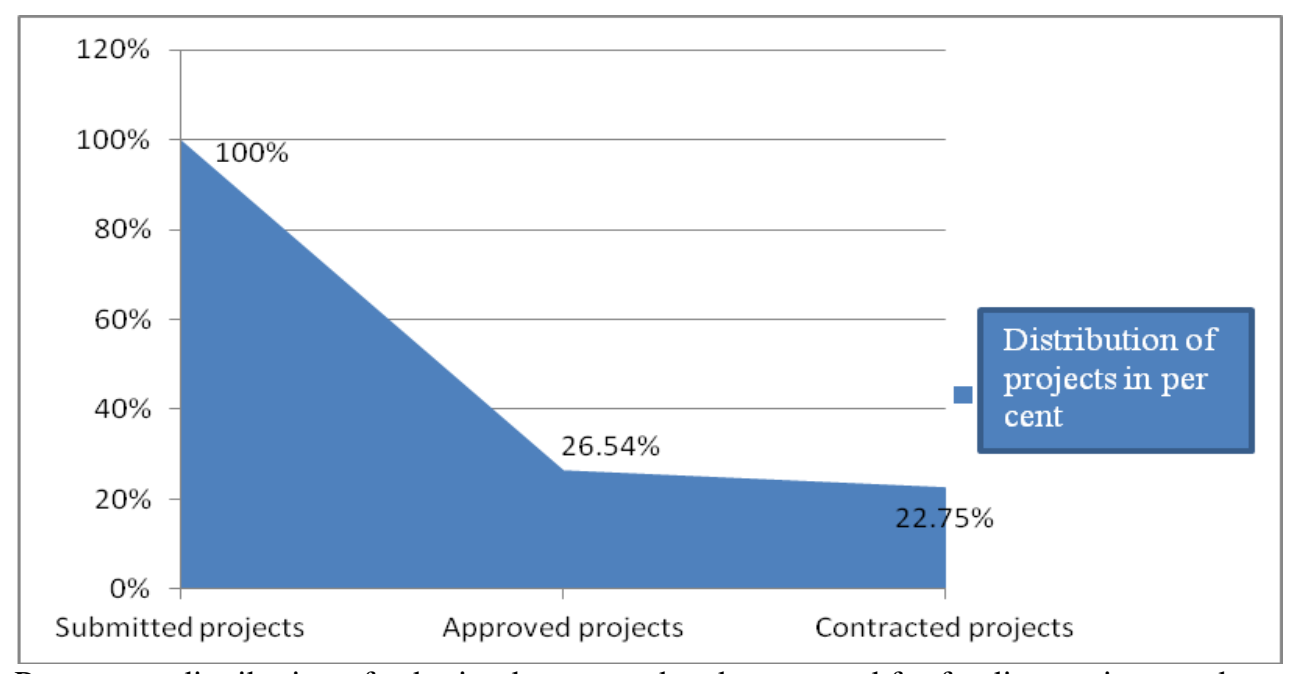

Figure 7. Percentage distribution of submitted, approved and contracted for funding projects under axes 4 and 5 of the Bulgaria Romania cross-border cooperation programme for the period 2014-2020

It can be seen that the share of funded projects is significantly less, namely $26.54 \%$ of all the projects received, but the number of contracts signed is very close to the percentage of approved projects. It is striking that under none of the axes, and none of the tranches there is a match between the approved and actually funded projects, which shows difficulties in procuring the initial funds for starting the implementation of the projects. It is a pleasing fact that there is a high level of activity of submission of projects during each of the calls periods and under each of the axes of the Romania Bulgaria cross-border cooperation programme. Thanks to this, a number of successful projects are being implemented, some of which are presented in the following table. 
TURLAKOVA T., et al.

Table 2. Some interesting projects under the bulgaria romania cross-border cooperation programme for the period 2014-2020

\begin{tabular}{|c|c|c|c|c|}
\hline $\mathrm{N}$ & Project name & $\begin{array}{l}\text { Main activities and } \\
\text { beneficieries }\end{array}$ & Project funds & Project result \\
\hline 1. & $\begin{array}{l}\text { "Balloon } \\
\text { adventure - a new } \\
\text { joint tourism } \\
\text { product" [9] }\end{array}$ & $\begin{array}{l}\text { The idea is implemented by } \\
\text { the Agency for } \\
\text { Development and Business } \\
\text { Center, Vidin, and the } \\
\text { Romanian Electronics and } \\
\text { Software Association. The } \\
\text { aim is to create a new } \\
\text { tourist product that has } \\
\text { impact in } 10 \text { cities on } \\
\text { Bulgarian territory and in } \\
10 \text { cities on Romanian } \\
\text { territory. }\end{array}$ & $\begin{array}{l}\text { The budget for the } \\
\text { implementation of } \\
\text { the project is } \\
\mathbf{4 8 5 , 4 6 0} \text { euros. } \\
\text { Two hot air } \\
\text { balloons have been } \\
\text { purchased within } \\
\text { the project. In the } \\
\text { period November } \\
\text { 10th - } 19^{\text {th }} \text {, 2016, a } \\
\text { balloon training } \\
\text { was organized and } \\
\text { conducted in } \\
\text { Montana. }\end{array}$ & $\begin{array}{l}\text { The project partners have planned } \\
\text { "balloon adventures" to } \\
\text { increase by } 2000 \text { the number of } \\
\text { overnight stays in the eligible cross- } \\
\text { border area }\end{array}$ \\
\hline 2. & $\begin{array}{l}\text { „Green school } \\
\text { education“. }\end{array}$ & $\begin{array}{l}\text { The aim of the project is to } \\
\text { promote the sustainable use } \\
\text { of the great cultural and } \\
\text { natural heritage and } \\
\text { resources. The project } \\
\text { partners are: Association } \\
\text { "Development Center } \\
\text { Montanesium", Montana, } \\
\text { Bulgaria and Association } \\
\text { "Forever for Europe", } \\
\text { Craiova, Dolj, Romania }\end{array}$ & $\begin{array}{l}\text { The funds } \\
\text { allocated under the } \\
\text { project amount to } \\
\text { EUR 693 880. }\end{array}$ & $\begin{array}{l}\text { Production and distribution of } \\
\text { educational and information films to } \\
\text { promote the cultural and natural } \\
\text { heritage of Montana and Dolj. } \\
\text { Five-day "green schools" have been } \\
\text { organised in Bulgaria for three age } \\
\text { groups of students: up to 12, up to } 14 \\
\text { and up to16 years of age. }\end{array}$ \\
\hline 3. & $\begin{array}{l}\text { „Valorisation of } \\
\text { the authentic } \\
\text { cross-border } \\
\text { tourism } \\
\text { culture }^{\text {". }}[9]\end{array}$ & $\begin{array}{l}\text { Association "Regional } \\
\text { Partnerships for Sustainable } \\
\text { Development - } \\
\text { Vidin", Cross-border } \\
\text { Association" E(quilibrum) } \\
\text { Environment" (C.B.A.E.E) } \\
\text { (Romania) and Agency for } \\
\text { Regional Development and } \\
\text { Business Center 2000, } \\
\text { Bulgaria }\end{array}$ & $\begin{array}{l}\text { The total value of } \\
\text { the project } \\
\text { amounts to EUR } \\
\mathbf{4 1 4} 300 \text {. }\end{array}$ & $\begin{array}{l}\text { Study objects are represented by a } \\
\text { total of } 210 \text { short videos made for the } \\
\text { regions of Vidin, Montana and Dolj. } \\
\text { A trilingual website for the project has } \\
\text { been } \\
\text { www.robgtraditions.com }\end{array}$ \\
\hline 4. & $\begin{array}{l}\text { "Development of } \\
\text { Danube River } \\
\text { Basin for Better } \\
\text { Connectivity of } \\
\text { Euroregion } \\
\text { Rousse - Giurgiu } \\
\text { with Pan- } \\
\text { European } \\
\text { Transport } \\
\text { Corridor №7" } \\
\text { under Priority Axis } \\
1\end{array}$ & $\begin{array}{l}\text { The main objective of the } \\
\text { project is "Increasing the } \\
\text { safety of transport on water } \\
\text { and sea routes" of the } \\
\text { Program "INTERREG V-A } \\
\text { Romania - Bulgaria" with a } \\
\text { duration of } 30 \text { months. }\end{array}$ & $\begin{array}{l}\text { The total cost of } \\
\text { the project is BGN } \\
\mathbf{1 4} \mathbf{3 6 9} \mathbf{1 6 2 , 3 9 .} \\
\text { Grants for Ruse } \\
\text { are in the amount } \\
\text { of } \\
\text { BGN } 9 \quad 002 \\
979.49, \\
\text { municipal the } \\
\text { contribution being } \\
\text { 180 059,57 BGN }\end{array}$ & $\begin{array}{l}\text { The project activities are related to the } \\
\text { construction of a quay at the side of } \\
\text { Giurgiu and the development of the } \\
\text { area around the St. George channel in } \\
\text { order to improve the connection with } \\
\text { the pan-European water transport } \\
\text { corridor. The Bulgarian municipality } \\
\text { will rehabilitate the quay walls of the } \\
\text { Rousse-Center passenger terminal and } \\
\text { will improve the navigation conditions } \\
\text { on } 3 \text { berths so that large passenger } \\
\text { ships can moor there. }\end{array}$ \\
\hline
\end{tabular}

Other interesting projects between the two countries developed under the cross-border program are: "Unlimited health through sport and cooperation - united in the fight against diseases". [14] This project has been developed under Priority Axis 5: Effective Region, Specific Objective 5.1 "Enhancing Cooperative Capacity and Effectiveness of Public Institutions in the Context of Cross-Border
Cooperation" under the Cross-Border Cooperation Program INTERREG V-A Romania - Bulgaria 2014-2020. The project's objective is: Joint development of new approaches in the field of public health at the level of local government in Shabla - Harshova border area. The main activities under the project are: improvement of the facilities in both municipalities, which involves the 
modernization of the Shabla Sports Hall and the stadium in Harshova, the purchase of specialized devices for the prevention of various diseases and the maintenance of a state of optimal lifelong health. The result of the project is to increase the capacity for cooperation between the two public institutions involved in the project but also their higher effectiveness in public health policy at local level, as well as conducting awareness campaigns to inform the public about the importance of sport in the health and sports activities with children and adults on the territory of the two cities. The project partners are 3: Shabla Municipality, Hursova Municipality and the Oyna Romanian Federation, with Harshova Municipality being the leading partner of the project. The maximum grant that is approved under the project amounts to EUR 1,489,666.82. The total budget of the municipality of Shabla is EUR 672,453.89. The co-financing by the municipality of Shabla as a partner amounts to $2 \%$ of its total project budget or EUR $13,449.08$.

One of the newest projects under the program called "Handling of Chemical and Biological Weapons, Radiological and Nuclear Weapons", as well as the project "Reconstruction and Provision of Cultural Sites with High Tourist Potential in the Euroregion Rousse-Giurgiu" is also provoking the researchers' interest. Under this project the pantheon of the Renaissance in Rousse has already been restored. All these guidelines are provoked by the ambition to improve and sustainably exploit the natural and cultural heritage of both countries as well as to preserve the environment and to promote resource efficiency by preserving and developing the natural and cultural heritage of the two regions, the whole Danube River and its estuary in the Black Sea. An interesting fact is that in most of the projects mentioned above leading partners are the Ministry of Economy and Culture or the Ministry of Environment and Water of Bulgaria and Romania, while often the district administrations of the seven Romanian cities Constanta, Dolj, Olt, Teleorman, Giurgiu, Calarasi, Mehedinti, and the eight Bulgarian cities - Vidin, Vratsa, Montana, Pleven, Veliko Tarnovo, Rousse, Silistra, Dobrich are leading parties in the project implementation. They are also the main project partners jointly with the capitals of the two countries Bucharest and Sofia. One of the last joint actions of the cross-border cooperation program is the creation of a "Climate Change Network and the Involved Risks" (the start of the project is June 2019).

Finally, we can summarize that all applications submitted under the cross-border co-operation program between Bulgaria and Romania show great economic and social interest in each of the three calls and the five axes of the program. The approved 79 financing contracts with a budget of over 101 million euros are real proof that the cross-border co-operation program between Bulgaria and Romania is a very important tool for handling common challenges and joint initiatives in the interest of the regions on both sides of the Danube river, connecting both countries and the rest of the European world with them.

Much of the approved and funded projects already have and will continue to contribute to the program's objectives and indicators. It is a positive fact that on the basis of these projects the social, health, cultural, transport, logistic, internet, administrative environment and infrastructure develop and conditions are created for understanding and new common horizons in the future realization of the economic activities of the two countries.

Due to the tourist and agrarian nature of the North and South Dobrudja region in the NorthEast region of Bulgaria and the Southeastern region of Romania, many of the projects are aimed at improving the cultural and tourist potential in the region and are related to creating a better road and telecommunication infrastructure and improving the conditions for forestry, fish farming and agribusiness.

All successful projects under the cross-border program between Romania and Bulgaria create the opportunity for future partnership between the two countries and even closer cooperation in different directions and aspects related to the economic, social and environmental wealth of the two regions.

\section{REFERENCES}

1. Todorova, M. - Scientific papers of the University of Rousse, 2013, volume 52, series 1.2, p.199

2. Regional Development Act, updated State Gazette, no. 50 / 30.05.2008; supp. SG. No. 13 of 7 February 2017

3. Kalinova, D. Regions in terms of the Regional Development Law, Scientific Works of the University of Rousse, 2015, vol. 54, series 7, p.189 
TURLAKOVA T., et al.

4. Regions 2020. An assessment of future challenges for EU regions, http://ec.europa.eu/regional_policy/sources/ docoffic/working/regions2020/pdf/regions2 020_en.pdf

5. Funding opportunities offered by the Interreg V-A Romania-Bulgaria Programme - Information brochure about Bulgaria-Romania cross-border programme - brosura-interregv-a-bg.pdf-June, 2019

6. Project implementation manual for projects financed under INTERREG V-A ROMANIA-BULGARIA-interregrobg.pdf, June, 2019

7. European Structural and Investment funds https:

//www.eufunds.bg/archive2018/index.php/b g/informatziya/ June, 2019

8. Interreg VA Romania-Bulgaria and the Strategy for the Danube Region. The Official Site of the Programme http://interregrobg.eu/en/ June, 2019

9. Ministry of Tourism, Republic of Bulgaria, INTERREG V-A Romania - Bulgaria Cross-Border Cooperation Program 20142020
10. http://www.tourism.government.bg/bg/vuz mozhnosti-za-finansirane/programa-zatransgranichno-sutrudnichestvo-interreg-vrumuniya-bulgariya- June, 2019

11. Purchase of technical assistance for elaboration of the future Cross-Border Cooperation Programme RomanianBulgaria for the period 2021-2027-https: //sicap-prod.e-licitatie.ro/pub/notices/cnotice/v2/view/100063087 - June, 2019

12. Ministry of Regional Development and Public Works- INTERREG V-A Romania Bulgaria Cross-Border Cooperation Program 2014-2020, June, 2019

13. https://www.mrrb.bg/bg/infrastruktura-iprogrami/programi-za-teritorialnosutrudnichestvo-2014-2020/interreg-v-arumuniya-bulgariya-2014-2020/, юни, 2019

14. Guide to EU funding, 2014-2020, Sofia, 2015, Ministry of Tourism of the Republic of Bulgaria rakovodstvo_eu_procects_2014-2020-1.pdf

15. Grazhdanska, Sv., PDF publication of Bulgarian Construction Chamber, Stroitel newspaper, INTERREG V-A RomaniaBulgaria is a pillar of achieving cohesion in the region, June 6, 2019 